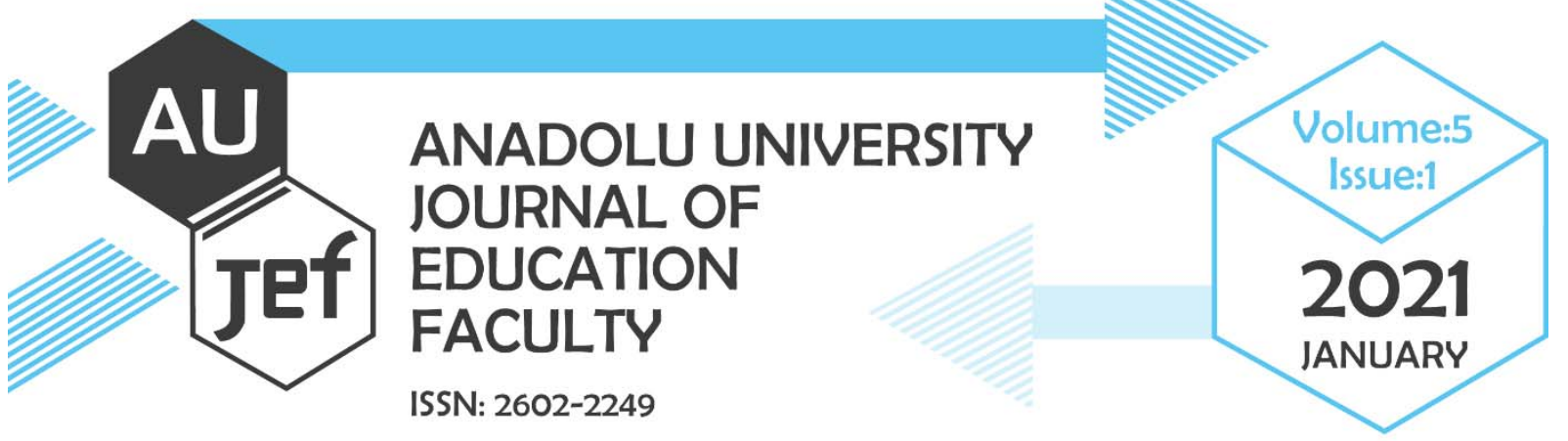

Edebiyatı EFL sınıflarına dahil etmede yenileyici bir duruş: Ken Liu'nun 'The Paper Menagerie' örneği

\title{
The menagerie of literatures: A renovating stance on incorporating literature in EFL classes based on 'The Paper Menagerie' by Ken Liu
}

Özge KURU ${ }^{1}$

\section{A. Nejat TÖNGÜR ${ }^{2}$}

Article Type: Review

Application Date: 01.09.2020

Accepted Date: 17.11 .2020

To Cite This Article: Kuru, Ö. and Töngür, A.N. (2021). The menagerie of literatures: A renovating stance on incorporating literature in EFL classes based on 'The Paper Menagerie' by Ken Liu. Anadolu University Journal of Education Faculty (AUJEF), 5(1), 108-126.

ÖZ: Edebiyatın, yabancı dil öğretiminde çok fazla firsat sunduğu genel olarak kabul edilse de İngiliz Dili Eğitimi'nde kullanılması tartışmalı bir konu olagelmiştir. Bu çalışmanın amacı, edebiyatın ELT sınıflarına dahil edilmesinin yabancı dil derslerini daha yenilikçi bir rotaya yönlendirdiğini göstermektir. Edebiyat eleştirel düşünme becerilerini, yaratıcılığı ve öğrenci özerkliğini geliştirmek üzere tasarlanmış geleneksel ve dijital olarak desteklenen iletişimsel aktivitelerle dil gelişimini destekler. Bu bağlamda kısa öyküler, öğrenci dostu uzunlukları, dil kullanımındaki yaratıcılıkları, barındırdıkları edebi unsurlar, konu bakımından geniş bir yelpazeye sahip olmaları gibi avantajları nedeniyle çok sayıda olanak sağlarlar. Bu çalışmada, kuramı pratiğe adım adım bağlamak adına, edebiyat, dil ve anlam yapılandırması kavramlarının ele alınışı, metin seçimi ve yöntem ile ilgili eleştirel tartışmaların akabinde Ken Liu'nun The Paper Menagerie (Kağglt Hayvan Koleksiyonu) adlı kısa öyküsü üzerinde sınıf içi uygulamalar önerilmektedir. Tüm okuma aşamalarını kapsayan bu aktiviteler, öğretmenlerin müzakereye dayalı bir sınıf ortamı yaratırken öğrencilerle iş birliği içinde olası sorunların üstesinden gelmelerine yardımcı olmak için tasarlanmıştır. Bu makale, edebiyat, dil ve anlam yapılandırmasına dair kendi anlamlandırmalarını yapan iç görülü öğretmenlerin öğrencilerinin yabancı dilde bağımsız bir okur kimliği kazanırken edebiyat gibi zengin bir kaynağın sahiciliğinden ve yaratıcılığından istifade etmelerini sağlayabileceği sonucuna varır. Edebiyat, ELT sınıflarımızı 21. yy. gelişmelerini yakalayacak şekilde yenilememize olanak sunmaktadır.

Anahtar sözcükler: Edebiyat, ELT, kısa öykü, dil becerileri, The Paper Menagerie

ABSTRACT: The integration of literature in English Language Teaching (ELT) has been a contentious issue although it is commonly accepted that literature caters to a whole bunch of opportunities for foreign language teaching. The aim of this study is to point to the idea that incorporating literature into ELT classes can direct foreign

1 M.A. Student, Maltepe University, Faculty of Education, Department of English Language Teaching, ozgekuru81@gmail.com, ORCID No: 0000-0001-7987-3661

2 Assist. Prof. Dr., Maltepe University, Faculty of Education, Department of English Language Teaching, nejattongur@maltepe.edu.tr, ORCID No: 0000-0002-1204-4399 
language classes into more innovative path as it fosters language development with both traditional and digitallysupported communicative activities designed to develop critical thinking abilities, creativity and learner autonomy. In this regard short stories, with their privileges due to their reader-friendly length, creativity in language use encompassing refined literary elements, and the wide range of subjects they deal with offer many opportunities. In this study to link the theory with real life experiences step by step, following the critical considerations about literature, language and meaning construction, text-selection and the methodology, possible applications based on the short story called The Paper Menagerie by Ken Liu are suggested. Activities encompassing all the phases of reading process are developed to help teachers to overcome potential difficulties in collaboration with their students while creating a classroom atmosphere based on negotiation. The article concludes that reflective teachers, starting to develop their own understanding of literature, language, meaning construction and reading, enable their learners to experience the authenticity and creativity of this valuable source when forming an identity as an independent reader of literature in the second language. Literature holds many opportunities to renovate language classrooms to keep up with the $21^{\text {st }}$ century improvements.

Keywords: Literature, short stories, ELT, language skills, The Paper Menagerie 


\section{INTRODUCTION}

In English Language Teaching (ELT), literature has been a victim of method-based approaches for ages. In traditional language teaching based on purely grammar teaching, literature has been given a "belletristic interpretation" (Lengyel, 1975, p.66). It is commonly assumed that literature was captured in an ivory tower and uprooted from daily life and that only the study of the canonical literature was allowed in learning a foreign language. Besides, language classrooms were restricted to prestigious "Literature with a capital L which is the classical texts", demising "literature with a small 1, which is then recognized as popular fictions, fables, song lyrics and so on" (McRae, 1994 as cited in Arafah, 2018 p.26). Although traditional approaches like the grammar-translation method were renounced, it did not suffice for literature to gain an authentic place in language teaching. Until the late 1980s, communicative competence and specific practical and functional purposes of skill-based approaches replaced audiovisual and grammar-translation methods and dominated ELT, which resulted in eliminating literary texts from the syllabuses. Language teachers often find themselves in the middle of a discussion between "literary scholars arguing for literature in the curriculum and angry applied linguists demanding exclusion of literature from the curriculum" (Lengyel, 1975 p.60). Approaches targeting the proficiency levels of the learners bloomed amid the uproar, and displayed that not only Literature but literature which includes the works of various writers from different background of countries and cultures using different forms should be employed to develop language acquisition. Literature, language and the perception of meaning are always changing. Teachers who can march with the times of change can reflect on their teaching methods to welcome new literary works and current technological opportunities in education, do not only integrate literature in their classes but they can also open a new door to the world of new literacies and literary genres which raise the learners as world citizens of the $21^{\text {st }}$ century. The reoccurrence of literature as an integrated component of the communicative language programs has brought about some new considerations to deal with.

\subsection{Critical Reconsiderations}

For different considerations a great many teachers were hesitant even resistant to the use of literature in their lessons; however, language teachers may critically reconsider how they conceptualize literature, what they understand from reading, how they perceive language and how they prefer to present literature in classes, i.e. their teaching methods in order not to be deprived of a valuable source. In other words, teachers who do not give up on literature in language classrooms and who try to include literary texts in language teaching have to adopt a new point of view which includes key factors such as welldefined objectives defining the role of literature and reading in relationship with language acquisition and meaning construction, text selection in the context of English as a Foreign/Second Language, contextualized effective integration procedures, and preparation in the area of literature teaching in EFL (Bobkina \& Dominguez, 2014; Carter, 2007; Lima, 2010). The context-sensitive pedagogical framework, the critical pedagogies, and English as a Lingua Franca Pedagogy in the post-method era promise a lot to strengthen the role of literature in language classes.

\subsubsection{Literature, Language, and Meaning}

Carter (2007) summarizes that the improvements in the field have led to an enhanced understanding of responses to literature and language in the classroom. In language teaching, the focus which was ruled by the Saussurian structuralism in which the text was considered as a monologic 
discourse of fixed meanings, and isolated from interaction between collocutors has shifted towards a more Bakhtinian view which introduces the dynamic construction of meaning in relation with form through succession of interactions. According to Bakhtin (1986) "there can neither be a first nor a last meaning; it always exists among other meanings as a link in the chain of meaning, which in its totality is the only thing that can be real" (p.5). Considering the fact that the act of reading is basically an act of meaning construction, language classes welcome classroom opportunities which enable learners to critically engage with texts so that they can perceive that interpretation and meaning are constructed within the critical reading process in social interaction. This new stance requires teachers who avoid asking questions with predetermined answers, and let multiplicity of voices and diversity in perception into meaning creation process. The learners are encouraged to bring their own voices to the chain of meaning. Bakthin (1986) opposes the separation of language use and language forms and teaching of separated linguistic elements such as vocabulary, grammar rules. Such an approach leads to a broader understanding of grammar, vocabulary, and semantics within meaning construction. Language and literature thus cease to be the discourses where learners deal with purely analytical processes to become the territory where language and layers of meaning are discovered (Lima, 2010). They create their own meanings when given in language classes.

Moreover, in his "Dialogized Heteroglossia" Bakhtin (1986) introduces primary genres (speech genres found in simple speech such as everyday conversation, journals and letters) and secondary genres (complex speech genres found in discourses such as novels, plays, academic reports) highlighting that learning happens through exposure to diverse speech genres within the local environment. Primary genres and secondary genres are in a dialectical relationship, namely everyday conversation and 'literary' forms coexist in mutual interaction. Such a view would enrich EFL classes with tasks which give learners more autonomy and responsibility to explore different layers of meaning in varied discourses and to see how they interrelate in order to form their own identity as a reader of literature in the second language. Consequently, learners and teachers collaboratively get in charge of the classroom activities in which reading skill is developed through critical thinking. As seen clearly, literature in language classes would give more autonomy to teachers and learners, and foster meaningful learning where agents can have a more independent voice.

\subsubsection{Literature and Methods}

The dispute around literature use in EFL classes which has made many teachers hesitant about integrating it in their programs resulted from method-based problems. As Bobkina \& Dominguez (2014) clearly state, there is no one single right way to use literature in the language classroom. On the contrary, they propose various approaches depending on the teaching needs. In the Post-Method era, in both theory and classroom practice, it is stressed that context-sensitive framework, rather than imposing best methods, contains activities which serve to goals, needs, and real situational realities of learners in a given context. Literature in this sense would give the chance to teachers to improve their instructions as much as the other discourses do, with infinite ways of interpreting the text through various classroom applications. Carter (2007) defines the appropriate method as the one which takes each text on its own merits, uses what the reader knows, what the reader is aiming for in his or her learning context, and employs all of the available tools, both in terms of language knowledge and methodological approaches. When the learners actively participate in the process as explorers of meaning in literary texts in EFL classes, they raise awareness of and an interest in the process itself, including the development of linguistic structures to produce reflections on it. 


\subsubsection{Literature and Literatures in English}

The spectrum of literature has been broadened to include the digital literature or electronic literature which is a genre including works created or coded in digital environments. Similarly, Bernstein (2013) focuses on the opportunities "to teach in English about writers and writings from the world without colonizing or excluding other languages and cultures" (p. 54). It is a vicious circle to restrict classes to canonized works of Literature with capital $\mathrm{L}$ rather than adopting a broad understanding of the literature of the era, and then claim that literature is associated with outdated poetic language, and it is no use for the twenty-first century English speakers on the streets. It is actually the authentic language people normally use in literary or daily discourses.

Teachers who create a more inclusive notion of world literature in a learning process whereby students turn into active participants of world literature development can increase students' awareness and understanding of the role that literature and writers play concerning global issues and relationships. In the past twenty years, the extensive developments in the codification of new englishes have brought about the insertion of literary texts in new englishes into pedagogical frameworks (Carter,2007). This points up the importance of literature as mediation to explore cultures. However, it should also be noted that with a superficial knowledge of a foreign literature learners can only end up with "false assumptions and false ideas (notably, stereotypes) about the society and culture it reflects and is addressed to" (Lengyel,1975, p.62). The study of literatures in English in a foreign-language class can disclose varied aspects more vividly as literature gives one awareness of human insight. Literatures in English and digital literature open new doors for learners who would belong to a multicultural world without prejudices.

\subsection{The Methodology of Integrating Literature in EFL}

The question of how to use the chosen literary text in EFL classes gave cause for a different methodological approach to the integration of literature in EFL classes. In a context-sensitive framework teachers can make use of and adapt the current methodologies according to emergent needs of students and their perception of language and literature. Carter and Long (1991) explaining multiple advantages of literature in the field of language teaching developed three models for integrating literature to EFL classes (as cited in Bobkina \& Dominguez, 2014). The basic premises of them are noted down as follows:

In the Cultural Model the priority is on the cultural elements within the literary work through social, political, literary, and historical perspectives. Literature is seen as a door to cultural accumulations of societies or individuals as in biographies. It is one of the best ways to understand the culture of the target language, especially when a visit or a stay is virtually impossible (Collie \& Slater, 1987).

In the Language Model literature aims at language development and awareness. Without any attention to literary quality, literary texts serve as an authentic source of contextualized linguistic features such as real examples of styles, text types, and registers to be studied in a wide range of classroom activities.

According to the Personal Growth Model literature caters to opportunities in which students can gain personal experience in the reading process. Learners interact with literary texts in order to enhance their personal development and language awareness. Literary texts are the resources which activate students' imagination, develop their critical thinking skills, and increase their emotional self-awareness and empathy. Throughout the story, they have chances to observe the characters and understand the reasons behind their acts, and connect the flow of events, which help them gain real lifelike experiences. 
On the other hand, Lengyel (1975) advises steps to handle a literary passage starting from a linguistic-semantic interpretation before jumping into the level of "pure" ideas. When the teacher impatiently asks questions about the author's way of thinking during the process of composition, the joy of reading good stories may be killed in the classroom discussions. Another contribution to the roadmap for teachers comes from Butler (2002) who divides attitudes towards literature in EFL classes into two groups, which gives teachers a foundation to think about their own stance: language through literature and literature through language. In language through literature, literature provides an authentic context for the teaching of grammar and vocabulary in meaningful debates, and develops the learner's linguistic and communicative competence, overall language awareness, interpretive and analytical skills and insights into the norms and cultural values embodied in the language while addressing to affective factors to be "the whole person". The study of literature through language, on the other hand, allows the learners to compare different discourses in language, link the study of literary texts to creative language activities and develop sensitivity to how language is used in a literary text.

Literary competence and linguistic competence with communicative competence are all interwoven and mutually interdependent. Learners need one to develop the other, which is fostered through the integration of language and literature. A mid-approach between the critical and the stylistic approach which does not consider linguistic and literature studies mutually exclusive fosters greater motivation, engagement with the text and awareness of the language functions.

\subsection{Short Stories}

There is broad consensus on the idea that short stories are an ideal way of introducing students to literature in the foreign language classroom. Students and sometimes even teachers are always worried about the amount of overwhelming work the study of literature may require, yet short stories seem to imply less frightening content. Short stories are believed to supply all the benefits of literary work with less effort within the economy of language. Although they are relatively short in length, short stories are rich sources of linguistic elements and include representation of characters of real and symbolic acts within the real or fictitious events. Collie \& Slater (1987) list the advantages that short stories offer as follows:

- It takes one or two class lessons to cover them thanks to their practical length.

- It is easy to tackle or to reread for the teachers, and are more suitable when set as home tasks to be completed sooner. Short stories are not complicated for students to work with on their own.

- They offer greater variety than longer texts, which appeals to each individual's tastes and interests.

- Short stories can be used with all levels (beginner to advance), all ages (young learners to adults) and all classes. (p.196)

Moreover, short stories with the world of fantasy and mystery in them give students opportunities to use their creativity through critical thinking skills. As they address to readers of various backgrounds thanks to their universal language, communicative activities are easily adaptable to them for negotiation of meaning. The reflection on the available suggestions in literature in EFL classrooms may help instructors who try to include literature in their classroom; for they need more pedagogically-designed appropriate materials, preparation in the area of literature teaching in EFL programs, forming clear-cut objectives, and necessary training in that field. This study works on The Paper Menagerie by Ken Liu 
(2011). In an integrated approach, The Paper Menagerie with its controversial plot on familial relationships, social discrimination, cultural stereotypes and the inner struggle of a child and his mother may enable students to develop personal insight into the socio-cultural problems while they compare the story with their own experiences. There are a lot of references to Chinese culture in the text, which can broaden readers' views multi-culturally. The flow of the text presents contextualized linguistic items and an example of fantasy as a genre for stylistic studies.

\subsubsection{How To Select A Literary Text}

It is commonly accepted that the success of literature use in the language class $\neg$ room mainly depends on the choice of literary work. An effective text selection is related to how to choose as well as what to choose. The steps to be taken while deciding on a text may also shape the whole pedagogical process to deal with literature in EFL classes and help teachers to prevent possible problems. Therefore some related issues to be considered by teachers can be suggested with specific reference to The Paper Menagerie as follows:

Need analysis in collaboration with students: In a negotiated curriculum approach, the planning of the materials is included in the teaching process. Discussing what to read with students would raise consciousness about literature, their own interests, and their needs so that they can internalize a responsible reader attitude. Lima (2010) recommends that as far as possible, teachers should let the students choose the text they want to read using online resources such as http://www.erfoundation.org/erf/. Alternatively, a social networking site post including the teacher's suggestion can be used for the text selection. Students post their own suggested book covers online and in class time, they reflect on why they recommend a particular text.

Non-restrictedness in genres: Teachers let the learners meet the rich world of literature with varied genres and materials illuminating global multi-cultural experiences and different aesthetic values so that students can have a voice about the choice of the text. Courses can be based on multiple extracts, short stories, poems, or drama, or lengthier texts. Yet, a classroom where literature is limited only to Shakespeare's sonnets and plays or graded readers students are not given chances to enjoy different works such as digital literature including hypertexts, Twitterature and Instapoetry, or books that put modern spins on classic fairy tales such as Interstellar Cinderella or Ninja Red Riding Hood.

Literatures in world englishes can also attract students to the contemporary world of literature. The Paper Menagerie is a short story which spans science fiction, fantasy and magic realism. It became the first work of fiction to win the three science fiction major awards; Nebula, the Hugo, and the World Fantasy Award. It was written in 2011 by Ken Lui who is a first-generation immigrant from China. Like the other new englishes which have been legitimized as World Englishes (WE) by Kachru, "China English" was proposed to be regarded as a variety of English in the WE framework (Fang,2017). It is chosen to raise awareness of WE in literature and to encourage learners to put attention into the contemporary works, yet the goals of the course do not include any detailed analysis of the structural differences of WE. The multi award-wining story caters to opportunities to present how accessible contemporary works are.

Syntactic and lexical accessibility: The complexity of grammatical structures and the complexity of ideas should be taken into consideration by the instructor, and materials should be developed accordingly even when students take an active part in the text selection process. Too difficult texts may hinder students' inference of the meaning of particular lexical items while too easy ones lack the 
challenge for motivation and vocabulary gain; thus, careful selection of texts and task designing can ease down the lexical difficulty objections. Because of the authentic simplicity of grammatical structures and the easy-to- follow flow of the plot, The Paper Menagerie makes itself a reader-friendly and motivating text for false beginner students. However, as it is assumed that when students achieve to read, comprehend and comment on an authentic text, they feel more competent in the target language as well, which might break the prejudices against second language acquisition while lowering anxiety. However, the story is also complex enough to foster the motivation for the practice of new structural items.

Multi- versioned representations: Literature generally reminds of long texts or verses; however, audio and visual adaptations of works of literature are easily accessible and ready to be used in classes. Film trailers based on novels, dramas on Youtube, graphic novels, audio books, or theatre productions all ease comprehension of lengthier narratives. Classroom activities related to comparing books and films to discuss omitted scenes can create authentic negotiation context for students to take part in. Multiversioned representations encourage students to engage cognitively and affectively in the text. The Paper Menagerie has an audiobook version and there is a short movie based on the story. The movie and different trailers produced by the fans are accessible on Youtube.

The reader-teacher: Finally, as a real member of the reading cycle in the class, the teacher should show real enthusiasm for the text to participate in real interaction and authentic exchange of ideas on the literary work, which motivates students. Teachers may prefer to take part in critical reflections to bind the text with real life instead of merely assessing students' comprehension.

\section{METHOD}

Literature with its multi-tiered content enables teachers to focus on only one skill or integrated skills within activities, tasks and exercises depending on the need analysis and the learning objectives. Arafah (2018) suggests varied types of teaching techniques which should be applied for using literature in EFL classes: analysing linguistic expressions, memorizing and producing to retell the story, completing lexical items, constructing a new story based on the current one, and transforming the literary work in another form (pp. 31-34). The activities suggested in this study exemplify each one of them in a rough lesson plan to set an example for linking the theory with actual classroom teaching. In the goal settings, the integration of Carter and Long's (2007) three models for integrating literature to EFL classes is followed, and this study focuses more on Personal Growth Model in which literature is seen as a bunch of opportunities for personal experience and personal development while students gain language awareness. The model also aims at creativity in the classroom, critical abilities, and affective development such as emotional awareness. All the activities were prepared in an approach which bases on the idea that interpretation and meaning are constructed within the critical reading process in social interaction. The flow of the lesson plan is designed in accordance with the basic classification by Lazar (1993) which was proposed to assist the teachers and learners to cope with possible problems arising in the literary work process.

\subsection{Pre-reading Activities}

To make meaning out of the literary work, students need to understand the cultural background of the story through scaffolding. These activities stimulate the students' interest in the story and pre-teaching some key vocabulary makes students feel more confident. 


\subsubsection{Picture Discussion}

The front cover of the book is shown to students to start a class discussion. The teacher asks critical thinking questions about the cover such as "Look at the picture on the front cover of the book. Why do you think a paper tiger instead of a real photo of a tiger is used on the cover?". Learners express their opinions. Students are advised to look "menagerie" up in their dictionaries. The teacher gives a brief explanation of a Chinese phrase and its equivalent in English. Paper tiger is a literal English translation of the Chinese phrase "zhǐlăohǔ". It means something that seems threatening, strong or dangerous, but is not really harmful. Students are asked to think about similar idioms or proverbs in English such as "its bark is worse than its bite" and in their own language.

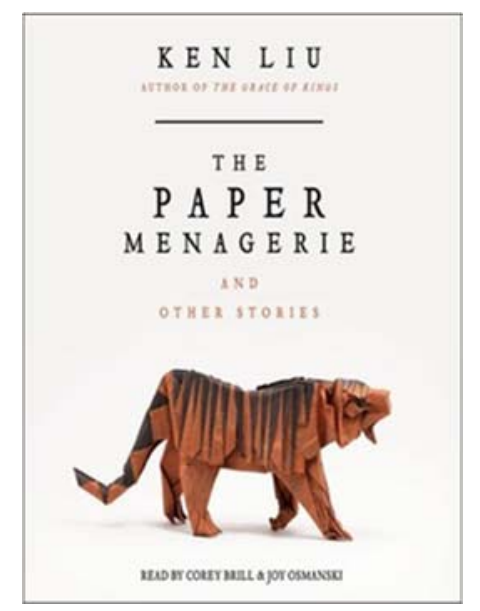

Figure 1. Front Cover of The Paper Menagerie (n.d.)

\subsubsection{Guessing the Line That Belongs to the Story}

Students are asked to look at the title of the story, check the date of publication, and the name of the author. They are given lines from three different stories to guess in pairs which of the given lines may be extracted from The Paper Menagerie. The line chosen here includes a sentence in Chinese to point to the cultural elements in the story.

- His wife called you nwanne, sister. They spoke Igbo and ate garri for lunch and it was like home.

- "Zhe jiao zhezhi," Mom said. This is called origami.

- “A merry Christmas, uncle! God save you!” cried a cheerful voice.

\subsubsection{Word Cloud Guessing}

A word cloud is used for pre-teaching key vocabulary and as a context to make students guess more about the story, and to express themselves. Students use their dictionary to check the meaning of the words they see in the word cloud prepared for this story on www.wordclouds.com, especially Qinming, sobbing, to tear, to cuddle up, to grab, to choke off, chink, to embarrass, orphan, and to smuggle. The teacher explains that Qinming is also known as Tomb-Sweeping Day in English. Chinese 
families visit the tombs of their ancestors to commemorate. The students are encouraged to look up the definitions of more words they realize in the word cloud.

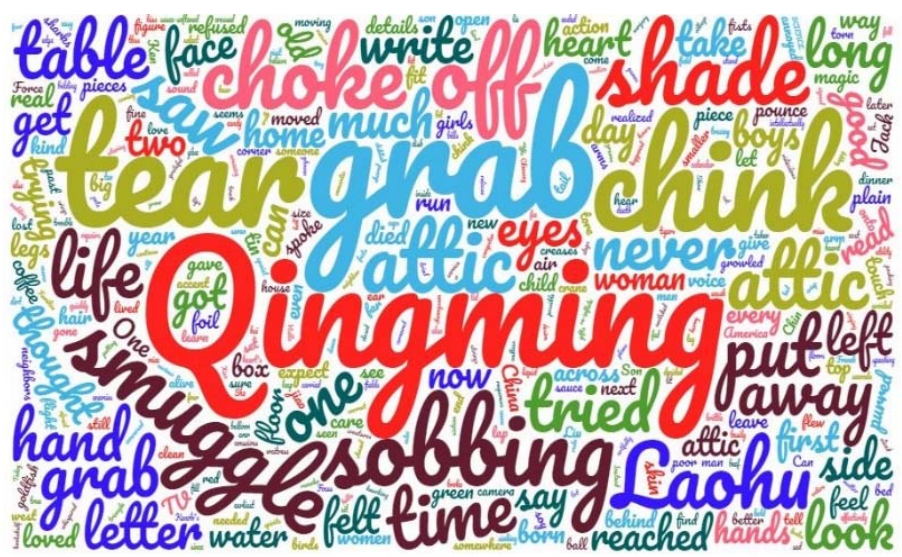

Figure 2. Wordcloud Created on www. wordclouds.com

\subsubsection{Extended Guessing}

Students work in pairs to guess about the outline of the story using the given starters and express their opinions to the class.

I think this story is about...

In my opinion, the setting is...

The main character...

The theme is...

\subsection{While-reading Activities}

These activities help students to understand the plot, the characters, the style and the language, and to come over lexical difficulties. Students are encouraged to work on the plot to construct their own meaning, the characters, the style and the language through while-reading activities. Before starting students are given the story a part of which was translated into Chinese in this study using Google Translation for a creative writing activity. In the original story, the letter is in English which will be handed out to students for further activities. Alternatively students are asked to scan the QR code to access the text in pdf, provided that the learners have smartphones to do so. QR codes can make the text accessible to the learners at any time and place, interesting and environmental-friendly.

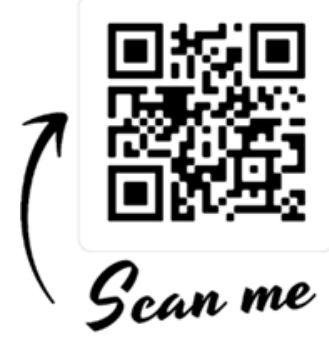

Figure 3. Paper Menagerie QR Code with the Letter in Chinese 


\subsubsection{Skimming}

The students skim the story to find answers to the questions below:

Write:

The name of an American toy

A Chinese dish

A cultural event in Chinese culture

A time period in the Chinese calendar

The name of a state in the U.S.

The name of a district near China

The word for love in Chinese

The teacher and the students can ask extension questions orally related to given titles. To give an example "Who has Obi-Wan Kenobi and who broke him?" or "Why is Hong Kong mentioned in the story?" can be posed to students.

\subsubsection{Writing A Character Caption}

Students are asked to complete the table to write a quote or two from the story by each character and explain why and how the sentences influenced them to indulge in the plot more. As literature in EFL classes caters to opportunities to integrate four skills after reading and speaking activities, students start to indulge in the story to analyze the characters and use the language reflectively to write about them.

\begin{tabular}{|c|c|c|c|c|c|}
\hline Jack & $\begin{array}{c}\text { Jack's } \\
\text { mother }\end{array}$ & Jack's father & $\begin{array}{c}\text { Their } \\
\text { neighbors }\end{array}$ & Mark & Susan \\
\hline & & & & & \\
\hline & & & & & \\
\hline
\end{tabular}

Figure 4. Character Caption Chart

\subsubsection{Chapter Headings for General Understanding:}

There are no chapter headings in the story. Students are asked to write a chapter heading summarizing the part. The literary text helps them to work on and develop comprehension and summarizing skills using the target language.

\subsubsection{Grammar Exercise:}

In the exercise, Jack, imaginatively, posted a photo of Obi-Wan Kenobi that his father bought for him on the Instagram. Students read the caption he wrote and complete it with the given verbs (stride upbring- break- tear- come over- punch- pay- leap at- choke- grab- spend) from the story. 


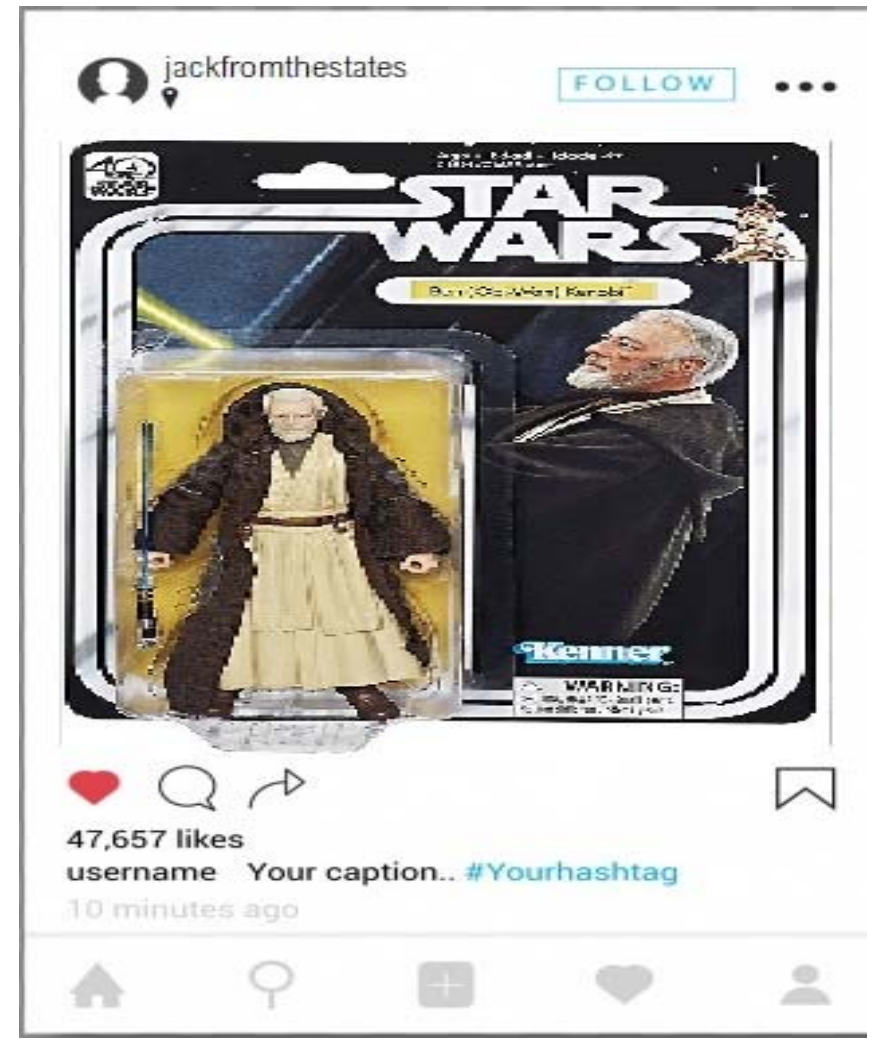

Figure 5. Instagram Photo Model

Check out what I have at home right now! Exactly! Star Wars action figures. Mark last week and we some time with together, playing his toys. Then I just asked a question, but Mark got annoyed. He wanted to see my toys. Lahou, my paper tiger Mark's Obi-Wan accidentally. What did he do? He hard and said they lots of money for it. When he called all my toys garbage. Laohu was angry at him too, it at Mark's face. I stood up and up to take Laohu. He it before me. Mark Lahou and it. My dad this to me to cheer me up.

\subsubsection{Guessing the Climax of the Story}

One of the most important literary elements in a story, climax is the the point of where the conflict or the tension reaches its high. In the present story, when Jack found out a letter written on paper animals in Chinese, the readers sense that the whole story is about to reach falling action phase. That the letter was written in Chinese makes the climax tenser as Jack cannot speak his mother's tongue. To make the students more curious and stimulate their creativity students are given a Chinese version of the letter that Jack's mom wrote to him before the story presents the English translation. Google translation was used to do so. In pairs, the students are told to act as translators to use their imagination to 'translate' the letter from Chinese into English. In other words, they are asked to write a letter to Jack from his mother. After they finish writing the letter, they watch a short film based on the story on Youtube (https://www.youtube.com/watch? $\mathrm{v}=\mathrm{h} 15 \mathrm{X}-\mathrm{Rz} 18 \mathrm{uw}$ ). Then they scan the QR code to read the original letter in the story and compare it with theirs and with the one in the film in groups. 


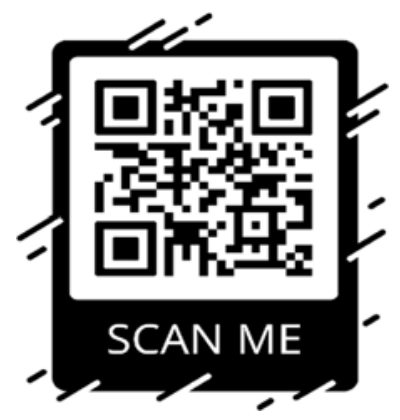

Figure 6. The QR Code for the Whole Book

\subsubsection{Recognizing the Literary Point of View}

In this activity which was adapted from Prestwick House Activity Pack- A Christmas Carol (2004) students are given selections from The Paper Menagerie and other three stories and novels, and are asked to complete the chart that follows them. Then, they need to answer the question below the chart. Before the activity the teacher gives a brief explanation about the different points of view through which works of fiction can be told, i.e., narrative voice. "Third-person" narrative is the perspective of a narrator who is not involved in the story. The third-person narrator can be either "omniscient" to 'know' everything, or "objective", meaning the narrator knows as much as the reader. On the other hand, the author chooses to tell the story from the perspective of a participant in the story, usually the main character in the firstperson narrative.

\begin{tabular}{|l|c|c|c|}
\hline \multicolumn{1}{|c|}{ The title } & $\begin{array}{c}\text { Point of View } \\
\text { (First Person/ Third } \\
\text { Person) }\end{array}$ & or Objective (Limited)? & $\begin{array}{c}\text { Omniscient } \\
\text { Narrator }\end{array}$ \\
\hline & & & \\
\hline $\begin{array}{l}\text { Compare the narrative voices of the given texts. Which of the above has the similar narrative voice to the one in The } \\
\text { Paper Menagerie? }\end{array}$
\end{tabular}

Figure 7. The Point of View Chart

\subsubsection{Jigsaw Summary}

Students cover the story and complete the flow of events in order. There is an extra event that does not belong to the story. Students are asked to cross it out in pairs.

Jack did not want to play with the menagerie. menagerie.

When his mom died, Jack discovered that she had been writing letters in the paper of his

Jack had a fight with Mark who teased him.

He wanted his mom to speak English. 
Her mom decided to move back to Chine.

Her mum grew increasingly silent and stopped talking when he was around.

When Jack's mom breathed into the origami, the menagerie came to life

As Jack grew up, he distanced himself from his mom.

Jack went out to find somebody to translate his mother's letters.

Jack's mom created an origami menagerie for him.

\subsection{Post-reading Activities:}

The activities which also fold into follow-up writing and fluency practices help students to make their own interpretations of the text and understand the narrative point of view. Students are encouraged to produce their own voices, relate the text with their own daily life and experiences, and interpret the text creatively in follow-up writing and fluency practices.

\subsubsection{Cultural Extension}

The students are asked to note down the information they get on Qingming in the story. The teacher goes to https://www.literacyshed.com/day-of-the-dead.html to give information about "Día de Muertos", a Mexican holiday like the Qingming in Chinese culture in the story. When online options are not available the teacher can use pictures to present the day. They watch a scene from a movie depicting this special day. They are asked to compare these traditions in terms of people's moods and what they do to commemorate their ancestors with the traditions in their own country. The activity aims to focus on the diversity of cultural traditions. In more advanced classes, or if the students are willing to do so, a class discussion on how different cultures perceive death can be initiated. The students are asked to reflect their personal opinions on Qinming and the Dia de Muertos in groups and in the whole class discussion.

\subsubsection{Writing A Diary in Pairs}

Students are divided into group A and group B to choose a day in the story to write a diary. Student A is asked to write about the event from the point of view of Jack, and student B writes for Jack's mother, explaining the day

- on which Jack shouted "Speak English" to his mother

- on which Jack visits her mother at the hospital

- on which Jack stopped playing with The Paper Menagerie.

Then they read their diary entries to compare and see how the same events are perceived by two characters. Provided that online sources are available, the learners can go to https://www.storyjumper.com/ produce online audio and written diary. They also design characters to include in their dairy to make an online book to be shared with others. Alternatively, they can produce an online story to attach and animate the characters in order to write a diary or a summary on different websites including https://cospaces.io/edu/. 


\subsection{Generative Genre Translation}

According to Bakhtin (1986), people have the capacity to think through a problem by dealing with it in a number of different texts. Different discourses or genres complete the parts of a point of view which is missing in other ones as they are interrelated forms of perceiving and interpreting varied aspects of the world. Dialectical translation of discourses also allows the learners to form their inner speech to share it with others. The learners can translate the short story into other genres. They are asked to write a daily conversation between Jack, his mother, and father about why Jack refuses to speak Chinese to his mother, or they can write a poem or song lyrics for Jack's mother. Alternatively, they can make a musical summary. They are asked to choose a song to reflect what impact the story made on them. They may prefer to translate an event from the story into emojis so that they can comment on each other's stories.

\subsubsection{Reflective Improvisation}

The learners are given roles to act spontaneously on a problem which is based on the story. The teacher or the learners can intervene to ask questions or reflect on the roles played by the learners. Dramatization without a script may include possible scenarios referring to social roles in relationships or customs. As an ethnographic reflection activity, improvisation may vary to assign different scenarios for each group on the same problem to act in order to perceive how different culture circles may react differently to the same issue, and that culture is a contextually shaped theme.

\subsubsection{Writing A Letter to A Character}

Students go to the web site https://www.futureme.org/ to write a letter to teenager Jack. They are going to give pieces of advice to Jack to avoid the communication breakdown between his mom and him. If writing skill is preferred as a post activity, this activity may foster creativeness of the students with a focus on linguistic elements as a constructing technique.

\subsubsection{Twitting Chapter Zero}

The class is divided into three groups to set the background of the story. Different narrator types will be assigned to groups: First-person narrator as Jack's mother, first-person narrator as Jack's father, and the third-person narrator. They write what happens before Jack was born.

\subsubsection{Culture Circles}

Paulo Freire (1972), proposes culture circles to reflect on the generative themes in the teaching material through codification. The picture below (Figure 8) from the book called "Problem posing at work: Popular Educator's Guide" by Auerbach and Wallerstein (1987) is supplied by the teacher as the codification to pose the problem, namely social discrimination. However, other themes suggested by the learners are welcomed to be reflected in the culture circles. 


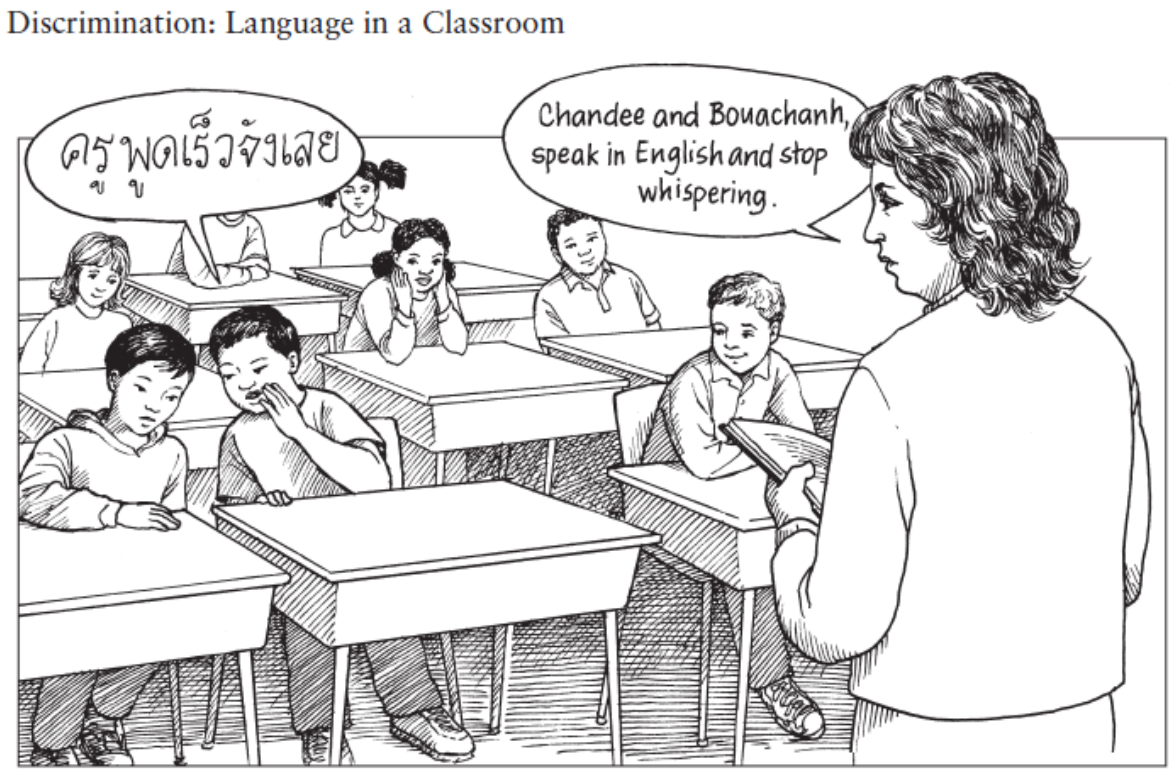

Figure 8. From Problem Posing at Work: Popular Educator's Guide by Auerbach and Wallerstein. Discrimination: Language in a Classroom. 1987

The students are asked some question to initiate classroom reflection section such as:

- How do you think these two students feel after they were told off by the teacher?

- Why do you think Jack gets annoyed by his mother tongue?

- What might he have experienced at his school during the classes and recess time?

After reflecting on the photo in relation to the story, the learners are encouraged to talk about their own experiences. In smaller circles, they are asked to come up with a solution to avoid discrimination at school. They note them down to act on them. Students are given chances to actualize their suggestions. To give an example, one group may want to write a classroom constitution against discrimination at school. As a whole class activity, students form the articles of it and sign it, and they can display it on a board or the school website.

\subsection{Whole-process Activities}

In addition to the abovementioned types of activities suggested by Lazar (1993), the whole-process activities can be included. These activities encompasses the whole literary study process from the beginning to the post-reading activities. They bare novelty as they are highly learner-centered activities in which learners act to organize and produce. They foster affective skills including personal communicative and collaborative traits while they motivate students to indulge in reading process responsibly and to interact with the literary text.

\subsubsection{Reading (Literature) Circle}

The traditional reading circle or the newer interactive counterpart of it on Web 2.0 tools (Hathaway, 2011) unfolds into various activities. There are lots of opportunities to create a web site on 
the Internet. A wiki site which serves people to share ideas and gives the opportunity to edit others' products by creating linking pages is one of them. In parallel with the traditional literature circle in the classroom, online circle allows students even more opportunities to be active co-participants and even co-authors of the text. Students form a group of five or six people to be assigned special roles such as discussion facilitator, travel tracer or figurative language finder. The roles may be dropped or modified according to students' interests. Some may be described as follows:

Discussion facilitator analyses the text critically to pose questions about the sections which may be of interest to students for discussion.

Connector or reflector points to the noteworthy passages in the story to connect them to real life events and characters or to the other stories that the class has read before.

Vocabulary enricher/Word Master /Word Wizard seeks for significant words in a passage.

Travel tracer notes down the setting such as countries, cities, buildings where the story reaches its climax or the major shifts occur. The student's role is to illustrate each setting in detail creating maps to trace the events.

Investigator supplies background information on the important topics such as historical events or cultural holidays in the story.

Illustrator is interested in visualizing the plot or characters. Drawing a portrait of the protagonist, making sketches of the leading scenes or creating digital visuals to explain an event may set examples for this role.

Figurative language finder: The identification of various types of figurative language, including metaphor, personification, hyperbole, and idiom is done by students. (Literature circle, n.d.)

\subsubsection{Reflective Reading Diary}

Students write their reflections on the reading process step by step starting from the text choice. It is an individual activity to become more self-aware as a reader. Students can reflect on their reading rate, skills, habits and reading activities to analyse their weaknesses and strengths in the reading process. The diary may also include unknown vocabulary, small notes about the plot, quotations from the story and scratches of characters or places. The activity helps to raise linguistic awareness and add more fun to reading process.

\section{RESULT}

Despite being very rich authentic sources, literary texts may be neglected and even underestimated in foreign language classes due to common method-based considerations ranging from historical reasons to very current issues. Other possible hitches may result from semantic, socio-cultural, lexical, and syntactic considerations, student needs, overloaded curricula and teachers' own previous experiences. Yet, literature being an everlasting part of a culture of a language has proved to be ineradicable in EFL classes. A new stance on the understanding of literature in its relation with language and meaning may reshape foreign language classes. Integration of literature involves the whole process from the text choice to the post reading activities. To do so, the steps to plan the course, namely choosing the material to be read in negotiation with students, introducing different genres, multiplying the representation of the written text and motivating students not a teacher but as a reader can be taken within a new scope. Teachers can also benefit from the different suggested methodologies in the field in their contextsensitive practices to merge them with their own experiences. 
The Paper Menagerie by Ken Liu with its linguistic simplicity and multi-tiered plot sets an example to use authentic novel literary materials for all age groups and for all levels. The story may also attract students' attention being the first work of fiction to win the three science fiction major awards. It may also be used to raise awareness on varied englishes all over the world, China English in this case. In this study some classroom practices including pre-, while- and post-reading activities are designed in accordance with analysing, memorizing and producing, completing, constructing, and transforming techniques within an integrated approach to Cultural, Language and Personal Growth models. It can concluded that when designed accordingly the classroom activities may create a context in which literary discourses can be worked on communicatively, creatively and collaboratively. With a sound planning of activities, literary components of a text such as genre, climax and narrative voices are easy to be involved in EFL instructions even with beginner students. This whole process is likely to enable students find and raise their own voices as independent readers. 


\section{REFERENCES}

Arafah, B. (2018). Incorporating the use of literature as an innovative technique for teaching English. KnE Social Sciences, 3(24). https://doi.org/10.18502/kss.v3i4.1914

Auerbach, E., \& Wallerstein, N. (2004). Problem-posing at work: popular educator's guide. Grass Roots Press: Edmonton

Auerbach, E., \& Wallerstein, N. (2004). Discrimination: Language In a Class. [Image]. Problem-posing at Work: Popular Educator's Guide. Grass Roots Press: Edmonton

Bernstein, L. (2013). Teaching world literature for the 21st century: Online resources and interactive approaches. Collected Essays on Learning and Teaching, 6, 54-59. https://doi.org/10.22329/celt.v6i0.3769

Bakhtin, M. (1986). Speech genres and other late essays. In W. McGee \& Michael Holquist (Eds). 60-102. Austin: University of Texas Press.

Bobkina, J., \& Dominguez, E. (2014). The use of literature and literary texts in the EFL classroom; between consensus and controversy. International Journal of Applied Linguistics \& English Literature. 3(2). http://dx.doi.org/10.7575/aiac.ijalel.v.3n.2p.248

Butler, I. (2002). Language through literature through language: An action research report on the English 100 course at the University of North West. Literator, 23(2), 33-50. Retrieved 06 August, 2020, from https://pdfs.semanticscholar.org/494b/c8d62659c53383ee0f7405929b9a271bf7d6.pdf

Carter, R. (2007). Literature and language teaching 1986-2006: a review. International Journal of Applied Linguistics, 17 (1). Blackwell Publishing Ltd. https://doi.org/10.1111/j.1473-4192.2007.00130.x

Collie, J. \& Slater, S. (1987). Literature in the language classroom. Cambridge, UK: Cambridge UP.

Fang, Fan. (2017). World englishes or English as a lingua franca: where does English in China stand?. English Today. 33. 19-24. https:doi.org/10.1017/S0266078415000668

Freire, P. (1972). Pedagogy of the oppressed. Hardmondsworth, Middlesex, UK: Penguin Books.

Hathaway, R. (2011). A powerful pairing: the literature circle and the Wiki. Virginia Tech. 38(3) https://doi.org/10.21061/alan.v38i3.a.2

Lazar, G. (1993). Literature and language teaching. Cambridge, UK: Cambridge UP.

Lengyel, G. (1975). The role of literature in teaching English as a foreign language. Angol Filológiai Tanulmányok / Hungarian Studies in English, 9. 59-70. Retrieved 6 August, 2020, from http://docshare01.docshare.tips/files/19285/192850814.pdf

Lima, C. (2010). Selecting literary text for language learning. Journal of NELTA, 15(1-2). 110-114. 10.3126/nelta.v15i1-2.4616

Literature circle (n.d.) Retrieved from https://en.wikipedia.org/wiki/Literature_circle\#Discussion_facilitator

Liu, Ken (2016). The Paper Menagerie. In The Paper Menagerie and other stories. London: Saga Press

Prestwick House Activity Pack- A Christmas Carol (2004). Prestwick House, Inc: Cheswold. Retrieved 6 August, 2020, from https://www.prestwickhouse.com/book/id-200781/christmas_carol_a_-_activity_pack 